\title{
ANALYSIS OF EXPERIENCE OF FOREIGN COUNTRIES IN ENSURING PUBLIC SAFETY
}

\author{
UO‘K: №: 64.3. M 64.
}

\author{
Haydarov Alisher Usmon o'g'li \\ Researcher of the University of Public Safety of the Republic of Uzbekistan
}

Article DOI: https://doi.org/10.36713/epra3602

DOI No: 10.36713/epra3602

\begin{abstract}
ANNOTATION
Each state on the basis of it'slocality and standards of life strives to ensure peace and tranquility, the rights and interests of citizens, public order and the prevention of violations. For this purposes all countries have structural units responsable for internal security. This article explores best practices of such developedcountries as Russian Federation, United States of America, Japan and China in the sphere of public security and relevant suggestions are formulated for further improvement of the activity of National Guard of the Republic of Uzbekistan in this direction.

KEYWORDS:National Guard, public order, public security, administrative territory, locality, maintenance of public order and security, preventive measures, interaction with the public, police stations and posts, commissioner of police,policeman, patrol and post service, sheriff.
\end{abstract}

\section{INTRODUCTION}

Ensuring public safety and providing a comfortable life for the population have been the main issues since the origin of the human society. Particularly, the ongoing struggles between ideas and ideologies during globalization and in the age of information are leading to a number of problems in ensuring public safety. In the world, each state has its own experience in ensuring public order and security and the use of these experiences in Uzbekistan contributes to the improvement of this system.

\section{LITERATURE REVIEW}

Research has been conducted in a number of foreign countries on the issue of public safety, the historical experience of its provision, the experience of ensuring public safety. These issues can be seen in the works of such researchers Voronov A.M 1 ,

\footnotetext{
1 VoronovA.M. Obshestvennaya bezopasnost': Administrativnie i informasionno-pravovie problemi obespecheniya. Avtoreferat dokt. diss. yurid. nauk. M.:2005. 56

s.URL: https://www.dissercat.com/content/obshchestvennayabezopasnost-administrativnye-i-informatsionno-pravovyeproblemy-obespecheni
}

Makarychev I.Yu², Belsona Ya.M, Bogdanova V.N, Bykova A.V, Veremeenko I.I, Gilensena V.M ${ }^{3}$, Belsona Ya.M,. Gilensena V.M, Gubanova A.B ${ }^{4}$.

\section{MAIN PART}

In the framework of the administrative territory (settlement) of any nation, activities to maintain public order and ensure public safety are carried out in different ways. Each country has its

\footnotetext{
${ }^{2}$ MakarichevI.Yu.Administrativno-pravovoe obespechenie obshestvennoy bezopasnosti organami munisipal'noy vlasti. Avtoreferat diss. kand.yurid. nauk. - Lyubersi:2010. 32 s.URL:

https://www.dissercat.com/content/administrativnopravovoe-obespechenie-obshchestvennoi-bezopasnostiorganami-munitsipalnoi-vl/read

SmorodinskovaIrina AleksandrovnaOrganizasionnopravovie osnovi deyatel'nosti Nasional'noy gvardii v obespechenii nasional'noy bezopasnosti SShA tema dissertasii i avtoreferata po VAK RF 12.00.14, kandidat yuridicheskix nauk

4 Bikov, Andrey Viktorovich Organizasionno-pravovie osnovi deyatel'nosti jandarmerii zapadnoevropeyskix gosudarstv $\mathrm{v}$ obespechenii obshestvennoy bezopasnosti tema dissertasii i avtoreferata po VAK RF 12.00.02, kandidat yuridicheskix nauk
} 
own experience in this area, and studying these experiences is one of the main requirements of the present day. The study of such experience provides an insight into the strengths and weaknesses of national structures aimed to ensure public safety. According to Vasilev D.V. studying the foreign experience, studying the factors influencing social development, determining the fundamental rules of development of society and its subsystem elements, and determining the prospects of the dynamics of social relations will create conditions to identify effective measures to address existing problems. ${ }^{5}$

According to Sharixin A.E, public security is a strategic priority of state national security ${ }^{6}$. The system of ensuring the public safety of developed countries differs from each other. The Russian Federation in this area has a great experience and the results of studying this experience allow us to come to conclusions to a certain extent.

In the Russian Federation (hereinafter referred to as Russia), "territorial police stations" play a significant role in maintaining public order and preventing disorders. The main purpose of organizing the service at such stations is to improve cooperation with public organizations and government agencies on the territories. Territorial police stations provide coordinated activities with self-governing bodies and the labor communities that are part of it. One of the main subjects of these stations is the police officers of the stations. Their activities are organized based on the decree of the Ministry of Internal Affairs of Russia (hereinafter the Ministry of Internal Affairs) № 1166 "On the organization of the activities of police station inspectors" dated December 31, 2012.7

The activity of police inspectors is a guarantee of the protection of citizens from various criminal threats in their places of residence. In the legal-normative documents of Russia indicated that the main service time of the police officers should pass in the areas under their primary duty, if necessary, they should be organized in the local police stations. In some regions of Russia, the post of assistant police inspector has been introduced, which increases the efficiency of work as a result of the

\footnotetext{
${ }^{5}$ Vasil'ev D.V. Konsepsiya organizasii deyatel'nosti polisii i vozmojnosti ix ispol'zovaniya $v$ otechestvennoy praktike: po materialam SShA i nekotorix stran Zapadnoy Yevropi. Avtoreferat dissertasii kand. yuridicheskix nauk. - M., 2005.

6 Sharixin A.E. Obshestvennaya bezopasnost' kak strategicheskiy prioritet nasional'noy bezopasnosti Rossii: vibor puti // Vestnik Moskovskogo universiteta MVD Rossii. № 6, 2015. - S. 238-243.

7 Ziyadullaev M.Z. Zarubejniy opit sistemi oxrani obshestvennogo poryadka i profilaktiki pravonarusheniy $\mathrm{v}$ naselennix punktax // Jurnal zarubejnogo zakonodatel'stva i sravnitel'nogo pravovedeniya № 2, 2017. - S. 21-34.
}

distribution of workload. ${ }^{8}$ The results of a survey of public opinion on police activities in the Russian Federation indicate that $83,3 \%$ of the population considers themself protected from encroachments on life, health, and property, 87,3\% expresses confidence in the ensuring security of personal and property to police inspectors. ${ }^{9}$

It is envisaged to involve citizens in the maintenance of public order and security, and an appropriate legal framework has been created to implement it. The role of patrol post-service inspectors in ensuring public order and security within the administrative regions is great. By patrolling in their territories, they ensure the identification of possible crime scenes, the identification of hidden criminals, cases of violation of the norms of law and morality by individuals, and the adoption of appropriate measures. ${ }^{10}$

The establishment of the Federal Service of the National Guard Troops of the Russian Federation by the Decree of the President of the Russian Federation No. 157 of April 5, 2016, led to public security in the Russian Federation to a new level. ${ }^{11}$

At present, the troops of the Russian National Guard, along with the police, are involved in maintaining public order and ensuring public safety. National Guard officers have broad authority in this regard. These include demanding from citizens to comply with public order and stop illegal actions, to take measures to protect the scene of the incident, prevent mass violations in the settlements of the people, and, if necessary, in the penitentiaries.

Although these powers of the Russian National Guard officers and militaries are close to the powers of the police, they have particular peculiarities. Citizens who have not fulfilled the legal requirement of the National Guard military

\footnotetext{
8 Buxarov D.Z. Jinoyatchilikning oldini olishda jamoatchilik ishtiroki: jahon tajribasi // Milliy qadriyatlar va shaxs ijtimoiy himoyasining huquqiy mexanizmlarini takomillashtirish: Respublika ilmiy-amaliy konferensiyasi materiallari. - Toshkent, 2007.

${ }_{9}^{9}$ Federal'naya slujba voysk Nasional'noy gvardii Rossii. Voprosi uchastiya $\mathrm{v}$ oxrane obshestvennogo poryadka i obespechenie obshestvennoy bezopasnosti [Elektronniy resurs] - Rejim dostupa: https:// cyberleninka.ru. - Data obrasheniya: 12.05.2020

10 Ziyadullaev M.Z «Zarubejniy opit sistemi oxrani obshestvennogo poryadka i profilaktiki pravonarusheniy $\mathrm{v}$ naselennix punktax» Jurnal zarubejnogo zakonodatel'stva i sravnitel'nogo pravovedeniya № 2. 2017 g. Buxarov D. Z. «Jinoyatchilikning oldini olishda jamoatchilik ishtiroki: jahon tajribasi» Milliy qadriyatlar va shaxs ijtimoiy himoyasining huquqiy mexanizmlarini takomillashtirish: Respublika ilmiy-amaliy konferensiyasi materiallari. Toshkent, $2007 \mathrm{y}$.

${ }^{11}$ Obzor rezul'tatov oprosa obshestvennogo mneniya o deyatel'nosti polisii (2019 god) [Elektronniy resurs] Rejim dostupa: https:// mvd.rf.ru . - Data obrasheniya: 08.05.2020.
} 
officer (personnel) are subject to administrative responsibility in the form of fines or arrest. ${ }^{12}$

The United States of America (hereinafter referred to as the US) is a country with a unique system and experience in maintaining public order and security in administrative-territorial units. The US police have a decentralized management system, which is based on the principle of "bottom-up", unlike European police systems. ${ }^{13}$

D.D.Shalyagin noted that having such a system of the American police is characterized by the history of the emergence of statehood on North America. ${ }^{14}$

Most local police agencies consist of sheriff's departments of the states. The sheriff is a reliable representative of the police, performing certain administrative functions in his district. The sheriff is an official who ensures public order and security in territories, the prevention of crimes, the establishment of anti-crime and the execution of punishment. Being responsible for the state of public order in the administrative territory, the sheriff has almost all legal powers. His activities are funded by the local budget.

In the major states of the United States, sheriffs are provided with service helicopters, cars, and motor vehicles, special task forces for special tasks. ${ }^{15}$ Experts who have studied the role and importance of patrol-post service personnel in maintaining public order and security believe that this service is the heart of the police. Due to the principle of a decentralized police system in the United States, patrol-post service is organized differently in different states, depending on the specifics of the states. According to US law, the US National Guard, which is considered a reserve army, can also be involved in public order and security in the event of an emergency. ${ }^{16}$

The US National Guard obey to the governors of the States in peacetime, and during the war to the President of the US.

\footnotetext{
${ }^{12}$ Klyuchevaya zadacha Rossiyskoy gvardii - bor'ba s terrorizmom i obespechenie obshestvennoy bezopasnosti rossiyskix grajdan [Elektronniy resurs] - Rejim dostupa: https://rosgvard.ru. - Data obrasheniya: 10.05.2020.

${ }_{13}$ Ziyadullaev M.Z. Zarubejniy opit sistemi oxrani obshestvennogo poryadka i profilaktiki pravonarusheniy $\mathrm{v}$ naselennix punktax // Jurnal zarubejnogo zakonodatel'stva i sravnitel'nogo pravovedeniya № 2, 2017.

${ }^{14}$ Shalyagin D.D. Polisiya SShA - organizasionnie i pravovie osnovi deyatel'nosti. Avtoref. dis. kand. yurid. nauk. - M., 1998. - S. 17.

${ }^{15}$ Sherifi v Soedinennix Shtatax [Elektronniy resurs] Rejim dostupa: https:// ru.qwe.wiki . - Data obrasheniya: 13.05.2020.

${ }^{16}$ Public security in Federal polities [Elektronniy resurs] Rejim dostupa: https:// books.google.co. - Data obrasheniya: 13.05.2020
}

Japan also has a unique experience in maintaining public order and security. In the settlements of this state, this function is performed by the lower joints - the posts and stations of the police. Realizing that one of the main directions of improving the activities of the police is to strengthen of public cooperation, the Japanese government pays special attention to the activities of the police "booths" (Koban) in the living quarters of the population. In Japan, such a system was founded in 1874. In general, such posts and stations are considered the basis of the Japanese police, almost $40 \%$ of staff work in them. ${ }^{17}$

Police posts are located in the villages, where one employee (Chuzaisho) resides with his family and conducts service activities. Police stations, on the other hand, are located in cities and provide only a service building for an employee. At present, $\mathrm{n}$ such stations, from three to five police officers serve, and they keep the public order in control through a large number of telemonitors and means of communication.

These police stations operate in the framework of a single system and play a significant role in enforcing the rule of law throughout the country. To date, 6300 Cobans and 6600 Chuzaisho activities have been organized on the territory of the state. Police officers working in Koban not only maintain public order but also help the population in difficult situations. ${ }^{18}$

Research conducted in Japan indicates the flexibility of these stations to the specificity of their territories in which they are located. Patrol and postservice officers working at posts and stations conduct regular patrols in the assigned territories and work closely with each family, organization, institution.

According to Japanese legislation, an average of 400 families are attached to each police officer. During the service, officers conduct explanatory work among the population within the framework of the preventive measures, provide them with the necessary information and study the social opinion on the activities of the police. In addition, there are "contact stations with police" in Japan, these stations provide for the activities of voluntary associations of citizens. Currently, there are about 700,000 such stations, each covering about 50 families. ${ }^{19}$

In Japan, the police organize and conduct their service activities without political pressure. The National Commission for Social Security, established by the Cabinet of Ministers of Japan, will

\footnotetext{
${ }^{17}$ Prestupnost' i kriminologiya v sovremennoy Yaponii / per. s yapon. O.A. Belyavskoy. - M.: 1989. - S. 154.

${ }_{18}$ Prestupnost' i kriminologiya v sovremennoy Yaponii / per. s yapon. O. A. Belyavskoy. M., 1989. S. 154

${ }^{19}$ Polisiya gosudarstv mira [Elektronniy resurs] - Rejim dostupa: https:// eurasialaw.ru . - Data obrasheniya: 10.05.2020.
} 
ensure the inviolability of the police system, protect the system from political pressure and maintain democratic methods of police management. ${ }^{20}$

The People's Republic of China (hereinafter referred to as the PRC), the world's leading country in terms of great number of population, also has extensive experience in ensuring public safety. The people's police of the PRC carry out most of these tasks. The People's Police of the PRC, in turn, is further subdivided into several types, and the public security police constitute one of these types. In order to ensure the safety and peace of the population, the public security police organize the round-the-clock service of the police officers, as well as the patrol officer service in the territories.

In order to perform these tasks, the police use the following methods of service:

a) Duty service at permanent posts. Duty service at permanent posts (guān chá shào) to ensure immediate movement in any situation. Besides observation in the posts, work is carried out to receive applications for crimes and irregularities from the local population, to assist the needy population.

b) Patrol service. In the conditions, if there is not the permanent post, the police officers carry out patrols in their territory, on foot, bicycles, cars, and motor vehicles.

c) Visiting service. Police officers, who are involved in the service in permanent posts, carry out regular visits to the places of residence and work of citizens living in the territory. During the visits, they provide citizens with suggestions on the prevention of crime and hear complaints from the people and suggestions on improving the quality of police service. They also register the population in their area.

In Shanghai and other major cities of the PRC, telephone communication between the police and the population has been established, and citizens can file complaints within 24 hours. Since 2005, more than 1,200 criminal cases have been revealed and about 5,000 people have been prosecuted. ${ }^{21}$

g) Consulting services. There are about 30,000 consulting services across China, each service consists of representatives of different social groups. Representatives of the group express their views and, together with the police, study and discuss the existing problems in ensuring public safety. In addition, contact groups are formed in order to prevent crime. The main task of contact

\footnotetext{
${ }^{20}$ National public safety commission [Elektronniy resurs] - Rejim dostupa: https:// ru.qwe.wiki. - Data obrasheniya: 14.05.2020.

${ }^{21}$ Osobennosti taktiki deyatel'nosti Narodnoy polisii Kitayskoy Narodnoy Respubliki pri nesenie slujbi [Elektronniy resurs] - Rejim dostupa: https:// cyberleninka.ru . - Data obrasheniya: 11.05.2020.
}

groups is to prevent crimes and create a healthy environment among minors. When the situation changes, the citizens belonging to the contact group, together with the police officers, carry out patrols and are involved in the implementation of propaganda work. The new Criminal Code adopted in 2006 is another important factor in ensuring a high level of public safety in the PRC. Experts believe that in many countries, some social acts that are considered disorderly are considered a crime according to the Criminal Code of the PRC. The death penalty is assigned for some types of crimes in PRC. ${ }^{22}$

\section{CONCLUSION}

Analyzing the experience of developed countries such as the Russian Federation, the United States, Japan and the People's Republic of China in ensuring public safety, we can conclude that:

firstly, the organization of round-the-clock service in every region of the country, including distant villages, can be the basis for the effective maintenance of public order;

secondly, in the issue of prevention of crime and law enforcement, it will be effective to set close contact with the local population, to visit their place of residence and work, to make appropriate recommendations and listen to their suggestions;

thirdly, strengthening the normative-legal framework of the state, adherence to the principle of inevitability of punishment for the committed misdemeanor, and increasing the legal literacy of the population is one of the important factors;

forth, in some cases, to allow those officials to make independent decisions in the cases of prevention and elimination of violations (in the questions of the involvement of forces and means in this series) ensure speed and timeliness in management.

Having studied the foreign system of ensuring public safety, I propose to take into account the following measures in the organization of the activities of the National Guard Of The Republic of Uzbekistan:

\section{SUGGESTIONS}

1. to develop measures to ensure close cooperation with self-governing bodies and the local population in the organization of activities to maintain public order and ensure the safety of the population in the living quarters, in the questions provision information, profiling of violations of the law and prevention of crime;

22 Ofisial'niy sayt Ministerstva obshestvennoy bezopasnosti KNR. [Elektronniy resurs] - Rejim dostupa: http://www.mps.gov.cn. $\quad-\quad$ Data obrasheniya: 10.05.2020. 
2. organization of visits of officers (employees) of the National Guard on duty to the homes (workplaces) of the population in the assigned territories and reporting at the end of the service (if necessary immediately) on the received appeals and proposals;

3. establishing of "National Guard Posts" in Mahallas where the criminogenic situation is unstable, until the situation stabilizes under the "Prosperous and Safe Mahalla" program.

\section{REFERENCES}

1. Vasil'ev D. $V$. «Konsepsiya organizasii deyatel'nosti polisii $i$ vozmojnosti $i x$ ispol'zovaniya $v$ otechestvennoy praktike: po materialam SShA i nekotorix stran Zapadnoy Yevropi. Avtoreferat diss.kand.yurid. nauk. - M., 2005

2. Sharixin A.E.«Obshestvennaya bezopasnost' kak strategicheskiy prioritet nasional'noy bezopasnosti Rossii: vibor puti»[Elektronniy resurs] - Rejim dostupa: https:// cyberleninka.ru. - Data obrasheniya: 08.05.2020.

3. Ziyadullaev M.Z. «Zarubejniy opit sistemi oxrani obshestvennogo poryadka $i$ profilaktiki pravonarusheniy v naselennix punktax» Jurnal zarubejnogo zakonodatel'stva $i$ sravnitel'nogo pravovedeniya № $2.2017 \mathrm{~g}$.

4. Buxarov D.Z. «Jinoyatchilikning oldini olishda jamoatchilik ishtiroki: jahon tajribasi» Milliy qadriyatlar va shaxs ijtimoiy himoyasining huquqiy mexanizmlarini takomillashtirish: Respublika ilmiy-amaliy konferensiyasi materiallari. Toshkent, 2007 y.

5. Obzor rezul'tatov oprosa obshestvennogo mneniya o deyatel'nosti polisii (2019 god) [Elektronniy resurs] - Rejim dostupa: https:// mvd.rf.ru . - Data obrasheniya: 08.05.2020.

6. Klyuchevaya zadacha Rossiyskoy gvardii bor'bas terrorizmom $i$ obespechenie obshestvennoy bezopasnosti rossiyskix grajdan [Elektronniy resurs] - Rejim dostupa: https://rosgvard.ru. - Data obrasheniya: 10.05.2020.

7. Federal'naya slujba voysk Nasional'noy gvardii Rossii. Voprosi uchastiya $v$ oxrane obshestvennogo poryadka $i$ obespechenie obshestvennoy bezopasnosti [Elektronniy resurs] - Rejim dostupa: https:// cyberleninka.ru. Data obrasheniya: 12.05.2020.

8. Sherifi $v$ Soedinennix Shtatax [Elektronniy resurs] - Rejim dostupa: https:// ru.qwe.wiki . Data obrasheniya: 13.05.2020.

9. Public security in Federal polities [Elektronniy resurs] - Rejim dostupa: https:// books.google.co. - Data obrasheniya: 13.05.2020

10. Prestupnost' $i$ kriminologiya $v$ sovremennoy Yaponii / per. s yapon. O. A. Belyavskoy. M., 1989. S. 154.

11. Polisiya gosudarstv mira [Elektronniy resurs] Rejim dostupa: https:// eurasialaw.ru . - Data obrasheniya: 10.05.2020.
12. 12.Nationalpublicsafetycommission [Elektronniy resurs] - Rejim dostupa: https:// ru.qwe.wiki. Data obrasheniya: 14.05.2020.

13. Osobennosti taktiki deyatel'nosti Narodnoy polisii Kitayskoy Narodnoy Respubliki pri nesenie slujbi [Elektronniy resurs] - Rejim dostupa: https:// cyberleninka.ru . - Data obrasheniya: 11.05.2020.

14. Ofisial'niy sayt Ministerstva obshestvennoy bezopasnosti KNR. [Elektronniy resurs] - Rejim dostupa: http://www.mps.gov.cn. - Data obrasheniya: 10.05.2020.

15. Shalyagin D. D. Polisiya SShA - organizasionnie i pravovie osnovi deyatel'nosti: avtoref. dis. . kand. yurid. nauk. M., 1998. S. 17.

16. VoronovA.M. Obshestvennaya bezopasnost': Administrativnie $i$ informasionno-pravovie problemi obespecheniya. Avtoreferat dokt. diss. yurid. nauk. M.:2005. - 56 s. https://www.dissercat.com/content/obshchestven naya-bezopasnost-administrativnye-i-

informatsionno-pravovye-problemy-obespecheni

17. 17.MakarichevI.Yu. Administrativno-pravovoe obespechenie obshestvennoy bezopasnosti organami munisipal'noy vlasti. Avtoreferat diss. kandidat yurid. nauk.-Lyubersi:2010.-32s.// https://www.dissercat.com/content/administrativ no-pravovoe-obespechenie-obshchestvennoibezopasnosti-organami-munitsipalnoi-vl/read

18. 18.Bikov, Andrey Viktorovich Organizasionnopravovie osnovi deyatel'nosti jandarmerii zapadnoevropeyskix gosudarstv $v$ obespechenii obshestvennoy bezopasnosti tema dissertasii $i$ avtoreferata po VAK RF 12.00.02, kandidat yuridicheskix nauk Moskva 1998 g 177 s. 